\title{
Taenia Hydatigena Cysticercus and Its Toxic Effects on Liver and DNA Profile in Sheep
}

\author{
Areej Bin Jumah ${ }^{1}$, Zohour Wanas ${ }^{1}$ and Hoda A Taha ${ }^{2}$ \\ ${ }^{1}$ Biology Department, Faculty of Science, Taibah University, KSA \\ ${ }^{2}$ Zoology department, Faculty of Science, Ain Shams University, Cairo, Egypt
}

\begin{abstract}
Cysticercosis of farm and wild animals is caused by the larval stages (metacestodes) of cestodes (tapeworms). Damage to tissues has been described in the cells of host infected with different species of Taenia. This damage is due to the increased amount of reactive oxygen radicals, which cause oxidative stress. Lipids, hepatocytic proteins and DNA are among the structures that are mostly affected by reactive oxygen and nitrogen species; resulting in functional and structural abnormalities, particularly in the liver. The objective of this work was to evaluate the impact of T. Hydatigena on oxidative modifications of hepatocytes in sheep. Liver samples were taken from domestic and imported sheep slaughtered in local abattoirs in Saudi Arabia. The effect of oxidative stress on hepatic tissue was studied by measuring biochemical parameters such as: glutathione, malondialdehyde, catalase activity, and glutathione S-Transferase assays. In addition, RAPD-PCR was carried out using three primers $\left(A P_{1}, A P 2\right.$ and $\left.A P_{3}\right)$ to investigate the changes in DNA fingerprints due to parasitic infection. Percentage of genetic variations were measured in the different sheep samples, which showed that the DNA profile of infected sheep were different from health sheep between 51-62\%. Generally local sheep were more affected than imported ones.
\end{abstract}

Key Words: liver toxicity, cysticercosis, biochemical measurements, Tania hydatigina, RAPD-PCR.

\section{Introduction}

Sheep comprise one of the most important livestock for Saudi Arabia and play an important role in the livelihood of a large portion of small and marginal farmers and nomads (Alshaikh et al., 2004). Parasites pose serious problems to the livestock industry, and as such are well worthy of the detailed attention required to explain how they cause disease (Dargie, 1980). Sheep liver is the target organ for many parasitic infections. It can be parasitised with different helminth infections such as Fasciola spp., Dicrocoelium and larval cestode infections such as hydatid cysts and cysticercosis (Thompson and Lymbery, 1995; Radfar et al., 2005; Ahmadi and Badi, 2011).

Infections with the larval stage of some species of Taenia are not only of public health importance, but also of veterinary significance because they cause economic losses due to banning infected offal or meat. The infection may lead to less production, or even death of the animals in cases of heavy infections.

Some stressors such asHeat, cold, drought, dehydration, infection, etc., result in cellular oxidative stress which is an imbalance between oxidation and anti-oxidation (reduction). Oxidative stress is a common mechanism contributing to hepatic damage and fibrogenesis in a variety of liver disorders. It can be monitored with several biomarkers (anti-oxidants and pro-oxidants), which can be assessed in plasma, erythrocytes, and liver. Superoxide dismutase, catalase, peroxidase, monoamine oxidase, glutathione reductase activities, glutathione ,ect., are considered as good serum markers of oxidative stress (Passi et al., 2001; Kataria and Kataria, 2005). Earlier studies have been carried outregarding the toxic effects and the oxidative stress of liver caused by parasitic infection in different hosts. Echinococcus granulosus and E. multilocularis(Smyth,1964), Fasciola hepatica (Castro, 1996; Calleja et al., 2000), Plasmodium falciparum (MikolajczakandKappe, 2006). Recently, several studies were carried out on the impact of parasitic infection on the hepatotoxicity and liver apoptosis. Mou et al. (2012) investigated the effects of Taenia asciatica and $T$ saginata on hepatocyte apoptosis in experimentally infected pigs. Also, Zebeda et $\boldsymbol{e l}$. (2016) studied the apoptosis in spleen CD4T cells, TGF- $\beta$ and Fox $\mathrm{p} 3$ gene expression in mice induced by $T$. crassiceps factor. The present study aimed to evaluate the oxidative modifications of sheep hepatocytes infected with metacestodes of Taeniahydatigenain local and imported sheep using a variety of relevant biochemical techniques. Also DNA profile of infected sheep was followed in comparison with normal ones using RAPD-PCR assay.

Chemicals

\section{Materials And Methods}

All common chemicals used were purchased from one of the following suppliers Sigma Co. (St. Loius, MO, USA). All other reagents were of the highest grade commercially available. (All chemicals used in the study were of analytical grade). 


\section{Samples collection and examination:}

Total of 120 Liver samples were collected from domestic and imported sheep slaughtered in local abattoirs in Medina (Medina slaughterhouse No. 7) in the Kingdom of Saudi Arabia during the periods of October 2013 to May 2014. The countries of origin of most of the imported samples are Sudan and Somalia.

The samples included 20 healthy liver used as control and100 naturally infected liver with larval cestodes. Out of the 100 naturally infected samples, 23 samples were collected fromlocal sheep while, 71 infected liver were collected from Sudanese sheep and 6 Somaliansamples. The identified samples infected with cysticercus of $T$. hyditagena were chosen from local and imported sheep. (10 samples for each).

After microscopic examination, the number, shape and arrangement of rostellar hooks were determined. Total lengths of large and small hooks were also measured using a calibrated eyepiece micrometer under oil immersion objective (Sweatman and Williams, 1963). The number of hooks was determined and the length of the hook and hook parts were measured as described by Hobbs $\boldsymbol{e t}$ al. (1990).

The collected liver samples were kept in two vials, one of them was stored at a temperature of $-86{ }^{\circ} \mathrm{C}$ until used for the physiological tests. The other part was kept in $70 \%$ ethyl alcohol for subsequent DNA analysis.

\section{Preparation of liver homogenate for biochemical investigation}

The hepatic tissues were homogenized in $10 \mathrm{ml}$ ice-cold phosphate buffer $(100 \mathrm{mM}, \mathrm{pH} 7.4)$. The homogenized tissue (1g of tissue $/ 10 \mathrm{ml} \mathrm{PBS}$ ) was centrifuged at 4000rpm for 15 minute .The supernatant was separated and stored at $-80^{\circ} \mathrm{C}$ for determination of oxidative stress markers and cellular defenses (MDA, GSH, GST and CAT).

\section{Assessment of oxidant/antioxidant activities}

Catalase (CAT),glutathione(GSH), glutathione S-transferase and malondialdehyde (MDA) levels were tested in the hepatic tissue homogenate.

\section{Bradford Protein Assay}

The solutions required for the Bradford protein assay was prepared using the following ingredients: phosphate buffer $(\mathrm{pH}$ 7.4), reactive Bradford agent, bovine serum albumin. The standard protocol for preparation was to put $5 \mu \mathrm{l}$ of phosphate buffer or different concentrations of BSA in the wells and adding 250 $\mu 1$ of the Bradford reagent to it. The samples were then prepared by diluting the supernatant five times, using $5 \mu \mathrm{l}$ of the sample, and $20 \mu \mathrm{l}$ of the phosphate buffer. After this, $10 \mu \mathrm{l}$ of the diluted extract and $250 \mu \mathrm{l}$ Bradford reagent were added to ELISA plates. The spectroscopic absorbance was read after 2 minutes at the wavelength of $595 \mathrm{~nm}$.

\section{Glutathione (GSH)}

The GSH assay was prepared according to the method described by Moron $\boldsymbol{e t}$ al. (1979). The assay is based on the reaction of GSH with DTNB (also known as Ellman's reagent) that produces the TNB chromophore, which has a maximal absorbance at $412 \mathrm{~nm}$, and the oxidized glutathione TNB adduct (GSTNB). The rate of formation of TNB, measured at $412 \mathrm{~nm}$, is proportional to the concentration of GSH in the sample. Glutathione is used as a standard to calculate the amount of GSH expressed as m mole of $\mathrm{GSH} / \mathrm{mg}$ proteins. The solutions required for this assay were :phosphate buffer $(\mathrm{pH} \mathrm{8),5 \%} \mathrm{TCA} \mathrm{solution,} \mathrm{used} \mathrm{for} \mathrm{protein}$ precipitation, $10 \mathrm{mM}$ DTNB solution (dissolved in phosphate buffer). $0.01 \mathrm{M}$ glutathione (GSH) solution was used as standard. The procedure of preparation was as follows: $50 \mu \mathrm{l}$ of solution (TCA) was added to $50 \mu \mathrm{l}$ of extract, $50 \mu \mathrm{l}$ TCA $5 \%$ was combined with $50 \mu$ lextract. The sample was centrifuged for 10 minutes at 14000 $\mathrm{rpm}$. The supernatant was then analysed for GSH content, which was done by adding $80 \mu 1$ extract, $120 \mu \mathrm{l}$ phosphate buffer and $20 \mu \mathrm{l}$ DTNB to the ELISA plate and measuring the absorbance at a wavelength of $412 \mathrm{~nm}$.

\section{Malondialdehyde Assay}

The MDA assay is based on the reaction of a chromogenic reagent, 2-thio-barbituric acid, with MDA at $25^{\circ} \mathrm{C}$. One molecule of MDA reacts with 2 molecules of 2 -thiobarbituric acid via a condensation to yield a chromophore (pink colour) with absorbance maximum at $532 \mathrm{~nm}$. In this study, the MDA levels were determined according to the method of Ohkawaet al. (1979). Levels of MDA were calibrated against a MDA standard curve, and expressed as mmole/mg protein. The solutions used were: $85 \%$ phosphoric acid, TBA 30 $\mathrm{mM}$ (MW=144.15g/mole), $\mathrm{KCl} 154 \mathrm{mM}$ (MW=74.55 g/mole), $\mathrm{H}_{3} \mathrm{PO}_{4}+\mathrm{TBA}+\mathrm{KCl}$ (Solution A), $\mathrm{H}_{3} \mathrm{PO}_{4} 1 \%$, $50 \mathrm{ml}$ TBA $30 \mathrm{mM}, \mathrm{KCl} 154 \mathrm{mM}$, TCA $5 \%$, MDA standard solution $(0.0627 \mathrm{~g} / 10 \mathrm{ml})$. The procedure was as follows: $25 \mu \mathrm{l}$ of extract $+250 \mu \mathrm{l}$ of Solution A were added to an ELISA plate, which was then incubated for $1 \mathrm{~h}$ at $65^{\circ} \mathrm{C}$. OD was read at $532 \mathrm{~nm}$. For measurements of the standard range, the extract was replaced by different concentrations of MDA. 


\section{Catalase activity assay}

The catalase activity was measured by the modified method of Cohen et al.(1996). Briefly, the cell lysate was incubated for 5 minutes in the presence of $6 \mathrm{mM} \mathrm{H}_{2} \mathrm{O}_{2}$ at room temperature. The reaction was then quenched by the addition of $0.75 \mathrm{~N} \mathrm{H}_{2} \mathrm{SO}_{4}$ and $50 \mathrm{mM} \mathrm{FeSO}$. The colour of the products formed was developed by the addition of potassium thiocyanate $(\mathrm{KSCN})$, and the absorbance of the ferrothiocyanate product was measured at $460 \mathrm{~nm}$. The standard curve of known activity of pure catalase was used to calculate the absolute values of test samples.

\section{Glutathione S-Transferase Assay}

The following solutions were used: $0.2 \mathrm{mM} \mathrm{GSH}, 5 \mathrm{mM}$ CDNB, phosphatebuffer(pH 7.4). The procedure was to add $5 \mu \mathrm{l}$ of the extract $+200 \mu \mathrm{l}$ phosphate buffer $+20 \mu \mathrm{l} \mathrm{GSH}+20 \mu \mathrm{l}$ CDNB onto the ELISA plate, after which the absorbance was read at $340 \mathrm{~nm}$ every 30 seconds, 4 times. For the blank the same was added but the extract was replaced with phosphate buffer.

Statistical analysis

The obtained data were analysed statistically using Prism Statistical software program to calculate T-test and ANOVA.

\section{CTAB method for DNA extraction}

DNA was extracted from the liver cell, the host of the parasite by CTAB precipitation method (Yap and Thompson, 1987).RAPD-PCR technique was carried out using three decimer (AP1: 5'-GGAAACCCCT-3', AP2: 5'-GGAAGTCGCC-3' and AP3:5'-GTAGGCCTCA-3'). The lyophilised primers were dissolved in sterile distilled water with a final concentration $100 \mathrm{p}$ mole $/ \mathrm{ml}$ for each primer. The PCR mixture contained $5 \mathrm{X}$ PCR buffer, $10 \mathrm{mM}$ dNTPS mixture, $25 \mathrm{mMMgCl}_{2}, 0.75 \mathrm{mMbovine} \mathrm{serum} \mathrm{albumin} \mathrm{(BSA)} \mathrm{(Sigma} \mathrm{Germany),}$ (2U) Taq DNA polymerase, 50 pmole) arbitrary primer, template DNA (according to the concentration of the cestode extracted for genomic DNA, the mixture volume was completed to $25 \mu$ with sterile $\mathrm{ddH}_{2} \mathrm{O}$.Amplification was carried out in ESCD swift max thermo cycler, Singapore.Thermal cycler was programmed for 45 cycles of 1 minute at $94{ }^{\circ} \mathrm{C}, 1$ minute at $36{ }^{\circ} \mathrm{C}$ and 2 minutes at $72{ }^{\circ} \mathrm{C}$. The amplification products were analysed by electrophoresis on $2 \%$ agarose gel in TAE buffer and detected by staining with ethidium bromide. The observed bands were scored as presence or absence for each group, and then the commonality percentages between all groups were calculated based on pairwise comparison between them for a particular primer, using the formula below, where Nxy: the number of shared bands between $\mathrm{x}$ and $\mathrm{y}$; and $\mathrm{Nx}$ and Ny: the number of bands in individuals $x$ and $y$ (Lynch, 1990):Commonality Percentage $=\mathrm{Nxy} /(\mathrm{N} x+\mathrm{Ny}) \times 100$.

\section{Results}

\section{Microscopic examination}

As shown in Fig.(1), the morphological characteristics of cysticerci recovered from the local and imported sheep under study were almost similar. Table (2) demonstrated the measurements of rostellar hooks and hook parts of cysticercus recovered from both local and imported sheep.

\section{Biochemical Results}

The determination of reduced glutathione (GSH), Malondialdehyde (MDA), Catalase enzyme activity(CAT) and glutathione $\mathrm{S}$ transferase, (GST) levels in liver tissues revealed a significant difference between control samples and infected ones of either imported and local sheep where the ratio of the mentioned parameters increased significantly in the infected groups compared to the respective control ones as described in Table 2.

\section{RAPD-PCR}

Out of ten tested arbitrary oligonucleotide primers, three primers of random sequences (AP1,AP2,AP3) produced recognisable fragments in RAPD-PCR and generated polymorphic DNA fingerprints of normal and infected livers for both imported and local sheep. As shown in Fig. 2, the primer AP1 produced polymorphic DNA fragments in the range of 100 to $1500 \mathrm{bp}$, most of which were reproducible with genomic DNA of liver isolates from sheep origin.. A dominant fragment of 280, $800 \mathrm{bp}$ was prominent in control local sheep isolates and absent in control imported sheep, while a fragment of $300 \mathrm{bp}$ was prominent in infected local sheep isolates and faint in infected imported sheep. In respect with the primer, AP2 (Fig.3), polymorphic DNA fragments in the range of 100 to $1500 \mathrm{bp}$, were produced most of which were reproducible with genomic DNA of liver isolates from sheep origin. A dominant fragment of 300-550 bp was prominent in control local sheep isolates and absent in control imported sheep, while a fragment of 700-800 bp was prominent only in infected local sheep isolates and faint in infected imported sheep. A dominant fragment of $100 \mathrm{bp}$ was prominent in control 
imported sheep isolates and absent in infected imported sheep, while a fragment of $1200 \mathrm{bp}$ was prominent only in infected imported sheep isolates and faint control imported sheep.

Fig. 4, showed the primer $\mathrm{AP}_{3}$ producing polymorphic DNA fragments in the range of 100-1500 bp. A dominant fragment of 500-800 bp was prominent in control local sheep isolates and absent in control imported sheep, while a fragment of 400-700 bp was prominent in infected local sheep isolates and faint in control local sheep. A dominant fragment of 250-500 bp was prominent in control imported sheep isolates and absent in infected imported sheep, while fragments of 350, 900, $1000 \mathrm{bp}$ were prominent in infected imported sheep isolates and faint control imported sheep. Percentage of similarity in imported sheep (SC) $49 \%$ and the proportion of the difference in imported sheep (DC) $51 \%$, while the percentage of similarity in the local sheep (SC) $38 \%$ and the proportion of variation in the local sheep (DC) 62\% (Table 5).The results showed that the infected local sheep was affected more than the imported one

\section{Discussion}

Cestode larval infections in sheep lead to inflammation as these larvae penetrate and imbed in tissues. Inflammation reactions are associated by production of ROS (Egwunyenga et al., 2004; Pal et al., 2006; Bello et al., 2000). The oxidative damage resulting from increased ROS production is destructive to cells and may lead to apoptosis and cell death (Beyer et al.,1996). Furthermore, the increased oxidative stress contributes to liver damage and fibrogenesis, and also leads to increased eosinophil production; which subsequently leads to mitochondrial injury and apoptosis of eosinophils(Serradell et al., 2009).

Additionally, earlier studies on malaria infection, high levels of oxidative stress markers have been observed in infected humans and rats in comparison to healthy controls (Clark and Hunt 1983; Sobolewski et al., 2005; Guhaet al., 2006; Sohailet al., 2007). Several tapeworm species that cause organ damage to mammalian liver have previously been studied. These include Taeniahydatigena, T.taeniaeformis, T. Crassiceps, Echinococcus granulosus and E. Multilocularis. Infestations have been observed to raise ROS levels that eventually lead to an increased oxidative stress index and a decreased total antioxidant capacity (Assady et al., 2011). The early stages of cyst development are usually accompanied by a concentration of eosinophils, neutrophils, and macrophages that surround the cyst (Zhang et al., 2003).

In their study, Li et al. (2004) described the functional protein and mRNA expression, along with the localisation of a peroxiredoxin from E. granulosus. Similar to our study, they observed fluid- filled bladders as hydatid cysts that develop in the internal organs of hosts. They also observed that the cyst survived under oxidative stress, and in the aerobic environment conditions induced by ROS. Glutathione plays an important role in detoxification reaction in liver and in regulating the thiol-disulfide status of the cell. Also, degradation of hepatic glutathione is regulated by the efflux of reduced and oxidised glutathione into bile and sinusoidal plasma. Under oxidative stress condition, the liver exports oxidised glutathione into bile in a concentrative manner, while under basal conditions, mainly reduced glutathione is exported into bile and blood.

However, Cunha et al. (2012) reported impairment of the liver GSH levels content in schistosomaisis infected mice. It was suggested that the antioxidant capacity of the liver decrease as a result of this type of infection. This subsequently leads to the generation of lipid peroxides that in turn play a further central role in the pathology associated with schistosomiasis. Accordingly, Hamed (2006) stated that after parasitic infection, glutathione levels were decreased. Gharibet al. (1999) explained that this decreased level of glutathione is attributed to the increased cytotoxicity with $\mathrm{H}_{2} \mathrm{O}_{2}$. The increased $\mathrm{H}_{2} \mathrm{O}_{2}$ occurred as a result of inhibition of glutathione reductase that keeps glutathione in its reduced form. In the present study, the determination of total GSH level in liver tissue revealed a significant difference between local control samples and infected ones, where glutathione ratio increased significantly in the infected groups compared to their respective control ones. Further, glutathione levels were higher in the infected local sheep than the infected imported sheep samples, at odds to (Kaplowitz, 1981).

Oxidative stress may result from increased production of free radicals due to increased MDA levels, an important lipid peroxidation marker. Generally, most parasites have to deal with the oxidative level inside their host cells. ROS and oxidative stress are the result of the aerobic metabolism that generates highly reactive metabolites of molecular oxygen in the cytosol, or in organelles such as the mitochondria or the peroxisomes (Andreyev et al., 2005).

In this study an increased level of MDA was reported in infected sheep. The MDA level was also higher in the infected imported sheep samples, compared to the infected local sheep samples. In addition, Glutathione S-transferase activity in liver tissue was significantly increased in infected sheep compared to control groups. Our MDA results are in agreement with studies that have found significantly increased levels of MDA in serum of human patients with fascioliasis when compared to controls (Kaya et al., 2007)and human patients with Plasmodium falciparumcaused malaria (Egwunyengaet al., 2004 and Ismail \& Al-Kennany, 2012). 
Catalase (CAT) is a clue of the antioxidant defence system. It plays an important role in keeping homeostasis and protection against oxidative damage through the remove of the toxic free radicals (EI-Shenawy et al., 2008; Jia et al., 2009).

The present data demonstrated that the activity of the liver tissue CAT of the infected sheep significantly increased as compared to control group. This is in agreement with the report of Kolodziejczyk et al. (2005) in their study on rats experimentally infected with Fasciola where they stated that catalase (CAT) activity in liver increased simultaneously with enhancement of lipid peroxidation processes as evidenced by the elevation of malondialdehyde (MDA). On the other hand, Rizk et al. (2012) recorded a reduced level in catalase activity in schistosoamsis infected mice and they attributed this to utilization of catalase in scavenging free radicals' overload, which generated during schistosomiasis infection

Severe discrepancies in the reactive oxygen species (ROS) level can induce oxidative modifications in the indispensable cellular macromolecules such as DNA, proteins, and lipids (Franco R. et al. 2007), ultimately leading to cell death. In normal aerobic cells, reactive oxygen species (ROS) are generated as a by-product of conventional mitochondrial activity. If uncontrolled properly, ROS can result in severe damage to certain macromolecules, especially the DNA. Therefore, we tried to trace the DNA changes in control and infected sheep through RAPD-PCR assay.

In the present study, RAPD-PCR procedures were carried out using three primers; AP1, AP2 and $\mathrm{AP}_{3}$.

All primer produced polymorphic DNA fragments (ranging from 100- $1500 \mathrm{bp}$ ), most of which were reproducible with genomic DNA of liver isolated from sheep. Certain fragments were prominently observed in control local and absent in control imported sheep. On the other hand, specific bands were prominent in infected local sheep and faint in infected imported sheep and vice versa. .

Percentage of similarity was measured between the different sheep samples; showing that the infected local sheep was more affected than the imported samples. In accordancewithLi et al. (2004), major biological macromolecules may thus be damaged caused by the oxidative stress of the highly unstable ROS; leading to strand breaks, DNA base modifications, lipid peroxidation and protein oxidation. This was investigated by Sharma et al. (2012) where they stated that The ZnO NPs induced oxidative stress led to DNA damage and apoptosis in the mice liver. They used comet assay, which revealed a significant increase in DNA lesions in liver indicating oxidative stress as the cause of DNA damage.

The results of the present study proved that RAPD technique is a useful tool for detection of DNA damage induced by parasitic infection in sheep. Similarly, Castano and Becerril (2004) used RAPD to assess DNA damage of the RTG-2 fish cell line after short- and long-term exposure to benzo (a) pyrene. By comparing DNA fingerprints from control and exposed cells, an increase in the instability in the DNA fingerprint of exposed cells over a time- and concentration-dependent manner was observed.

Also, Symonds et al. (2008) found that Methoxychlor (MXC) induce oxidative stress damage of DNA in breast cells and mouse ovarian follicles. Also, Methoxychlor produce adverse effects on reproduction that correlate with altered DNA methylation Patterns in the germ line of rats. In the same mannaer, Guidaet al. (2010) assessed DNA Damage by RAPD in Paracentrotus livid us Embryos Exposed to Amniotic Fluid from Residents Living Close to Waste Landfill Sites and they proved the ability of RAPD-PCR to detect and isolate DNA sequences representing genetic alterations induced in P. livid us embryos.

\section{Refernces}

[1] Ahmadi, N.A. and Badi, F. 2011. Human hydatidosis in Tehran, Iran: A retrospective epidemiological study of surgical cases between 1999 and 2009 at two University Medical Centers. Trop Biomedicine 28: 450-456.

[2] Alshaikh, M.A. ;Aljumaah, R.S. ; Al-Haidary, A. ; Alforaji, M.M. 2004. Genotyping and Improving Production Performance of Najdi Sheep in The Kingdom of Saudi Arabia. Department of Animal Production, College of Food and Agricultural Sciences, King Saud.

[3] Andreyev A. Y.; Kushnareva Y. E. and Starkov A. A. 2005. "Mitochon- drial metabolism of reactive oxygen species," Biochem, 70 (2): 200-214.

[4] Assady, M.; Farahnak, A.; Golestani, A. and Esharghian, M. 2011. Superoxide dismutase (SOD) enzyme activity assay in Fasciola spp. Parasites and liver tissue extract. Iran J. Parasitol. , 6(4): 17-22.

[5] Bello, A.R.R.; Fortes, E.; Bello-Klein, A.; Bello, A.A.; Llesuy, S.F.; Rabaldo, R.B.; Bianchini, A. 2000. Lipid peroxidation induced by Clinostomumdetruncatum in muscle of the fresh water fish Rhamdiaquelen. Dis. Aquatic Org., 42: 233-236.

[6] Beyer W., Glockner P., Otto J. and Bohm R. 1996. A nested PCR and DNA-amplification-fingerprinting method for detection and identification of Bacillus anthracis in soil samples from former tanneries. Salisbury Med. Bull., 87: 47-49.

[7] Calleja, C.; Bigot, K.; Eeckhoutte, C.; Sibille, P.; Boulard, C. and Galtier, P. 2000. Comparison of hepatic and renal drugmetabolising enzyme activities in sheep given single or two-fold challenge infections with Fasciola hepatica. Int. J. Parasitol., 30: 953-958.

[8] Castano, A.; Becerril, C. 2004. In vitro assessment of DNA damage after short- and long-term exposure to benzo (a) pyrene using RAPD and the RTG-2 fish cell line. Mutat Res., 552(1-2): 141-51.

[9] Castro, G.A. 1996. Helminths: Structure, classification, growth, and development. In:Med Microbiol (4th edition). Baron S. (ed.). University of Texas Medical Branch at Galveston, Galveston.

[10] Clark, I.A.; Hunt, N.H. 1983. Evidence for reactive oxygen intermediates causing hemolysis and parasite death in malaria. Infect.Immun. 39, 1-6. 
[11] Cohen, D.; Nisbett, R. E.; Bowdle, B. F. and Schwartz, N. (1996). Comparison of hepatic and renal drug-metabolising enzyme activities in sheep given single or two-fold challenge infections with Fasciola hepatica. Int. J. Parasitol.,30(8): 953-958.

[12] Cunha, G.M.; Silva, V.M.; Bessa, K.D.; Bitencourt, M.A.; Mace do, U.B.; Freire-neto, F.P.; Martins, R.R.; Assis, C.F.; Lemos, T.M.; Almeida, M.G.; Freire, A.C. 2012. Levels of oxidative stress markers: correlation with hepatic function and worm burden patients with schistosomiasis. ActaParasitol., 57, 160-166.

[13] Dargie, J.D. 1980. The pathophysiological effects of gastrointestinal and liver parasites in sheep. In Digestive PhysiolMetab in Ruminants.,pp 349-371.

[14] EI Shenawy, N.S., Soliman, M.F. and Reyad, S.I. 2008. The effect of antioxidant properties of aqueous garlic extract and Nigella sativa as anti-schistosomiasis agents in mice. Rev. Inst. Med. Trop. Sao. Paulo., 50: 29-36.

[15] Egwunyenga, A.O.; Isamah, G. and Nmorsi, P. 2004. Lipid peroxidation and ascorbic acid levels in Nigeria children with acute falciparum malaria. Afr. J. Biotech., 3: 560-563.

[16] Franco, R.; Schoneveld, OJ.;Pappa, A. and Panayiotidis, MI. 2007. Thecentralroleofglutathionein the pathophysiology of human diseases. Arch PhysiolBiochem., 113: 234-258.

[17] Gharib, B.; Abdallahi, O.M.; Dessein, H.; De Reggi, M. 1999. Development of eosinophil peroxidase activity and concomitant alteration of antioxidant defenses in the liver of mice infected with Schistosomamansoni. J. Hepatol., 30:594-602.

[18] Guha, M.; Kumar, S.; Choubey, V.; Maity, P. and Bandyopadhyay, U. 2006. Apoptosis in liver during malaria: Role of oxidative stress and implication of mitochondrial pathway. FASEB J. 20, E439-E449.

[19] Guida, M.; Guida M.; De Felice, B. and Santafede, D. 2010. Assessment of DNA Damage by RAPD in Paracentrotuslividus Embryos Exposed to Amniotic Fluid from Residents Living Close to Waste Landfill Sites. J. Biomed.Biotech.,Article ID251767, 7.

[20] Hamed, M.A. 2006. Excretory-secretory product of Fasciola hepatica worm protects against Schistosoma mansoni infection in mice. Indian J. Exp. Biol., 44, 554-561.

[21] Hobbs, R. P.; Lymbery, A. J. and Thompson, R. C. 1990. Rostellar hook morphology of Echinococcus granulosus (Batsch, 1786) from natural and experimental Australian hosts, and its implications for strain recognition. Parasitol. 101:273-281.

[22] Ismail, H. Kh. and Al-Kennany, E. R. 2012. Correlation of malondialdehyd and glutathione levels with pathological changes of sheep liver infected with hydatid cyst, Iraqi J., of Veterinary Science, Vol. 26, and an additional number 2. 151-157 (Proceedings of the Sixth Scientific Conference, College of Veterinary Medicine, University of Mosul.

[23] Jia J, Zhang X, Hu YS, Wu Y, Wang QZ, Li NN, Guo QC, Dong XC. 2009. Evaluation of in vivo antioxidant activities of Ganoderma lucidum polysaccharides in STZ-diabetic rats. Food Chem. 115:32-36.

[24] Kaplowitz, N. 1980. The physiologic significance of the glutathione S-transferases. Am J. Physiol., 239:G439-444.

[25] Kataria, N. and Kataria, A.K. 2005. Psychophysiological approach to alleviate stress in cattle. The Indian Cow.,2 (6), $2-5$.

[26] Kaya, S.; Sutçu, R.; Cetin, ES.;Aridogan, BC.; Delibao, N. and Demirci, M. 2007. Lipid peroxidation level and antioxidant enzyme activities in the blood of patients with acute and chronic fascioliasis. Int J. Infect Dis., 11(3): 251-255.

[27] Kolodziejczyk L, Siemieniuk E, Skrzydlewska E 2005. Antioxidant potential of rat liver in experimental infection with Fasciola hepatica. Parasitol Res, 96: 367-372.

[28] Li, J.; Zhang, W. B.; Loukas, A.; Lin, R. Y.; Ito, A.; Zhang, L. H. and McManus, D. P. 2004. Functional expression and characterization of Echinococcus granulosus thioredoxin peroxidase suggests a role in protection against oxidative damage. Gene., $326,157-165$

[29] Lynch, M. 1990. The similarity index and DNA fingerprinting. Mol. Biol. Evol., 5:584-599.

[30] Mikolajczak, S.A. and Kappe, S.H. 2006. A clash to conquer: the malaria parasite liver infection. MolMicrobiol.,62(6): 1499-1506.

[31] Moron, M. S.; Depierre, J. W. and Mannervik, B. 1979. Levels of glutathione, glutathione reductase and glutathione S-transferase activities in rat lung and liver. Biochim. Biophys. Acta. 582, 67.

[32] Mou R, Bao HE, Zhang K, Wu JH, Lang SY 2012. Study on hepatocyte apoptosis of domestic pigs experimentally infected with Taenia asiatica and Taenia saginata. Zhongguo Ji Sheng Chong Xue Yu Ji Sheng Chong Bing Za Zhi. 30:367-72.

[33] Ohkawa, H.; Ohishi, N. and Yagi, K. 1979. Assay for lipid peroxides in animal tissues by thiobarbituric acid reaction. Anal Biochem95: 351-358.

[34] Pal, B.K.; Kulkarni, S.; Bhandari, Y.; Balaji, B.; Ganesh, K.; Goswami, K. and Reddy, M.V.R. 2006. Lymphatic filariasis: possible pathophysiological nexus with oxidative stress. Trans. Royal Soc. Tropical Med. Hygiene 100: 650-655.

[35] Passi, S.; Stancato, A. and Cocchi, M. 2001. A monitoring of oxidative stress of ageing and ageing-related diseases. Prog. Nutr.,3, 35-58.

[36] Radfar, M.H.; Tajalli S. and Jalalzadeh, M. 2005. Prevalence and morphological characterization of Cysticercus tenuicollis (Taeniahydatigena cysticerci) from sheep and goats in Iran. Veterinarian Arhiv.,75 (6), 469-476.

[37] Rizk M, Ibrahim N ,. El-Rigal I N. 2012. Comparative In vivo antioxidant levels in Schistosoma mansoni infected mice treated with praziquantel or the essential Oil of Melaleuca armillaris leaves. Pak. J. Biol. Sci., 15 (20): 971-978

[38] Serra dell, M.C.; Guasconi, L. and Masih, D.T. 2009. Involvement of a mitochondrial pathway and key role of hydrogen peroxide during eosinophil apoptosis induced by excretory-secretory products from Fasciola hepatica. MolBiochemParasitol., 163(2), 95106

[39] Sharma, V.; Anderson, D. and Dhawan, A. 2012. Zinc oxide nanoparticles induce oxidative DNA damage and ROS-triggered mitochondria mediated apoptosis in human liver cells (HepG2) Apoptosis.,852-870.

[40] Smyth J.D. 1964. The biology of the hydatid organisms. Adv Parasitol., 169-219.

[41] Sobolewski, P.; Gramaglia, I.; Frangos, J.A.; Intaglietta, M. and Heyde, H.V.D. 2005. Plasmodium berghei resists killing by reactive oxygen species. Infect. Immun., 73, 6704-6710.

[42] Sohail, M.; Kaul, A.; Raziuddin, M. and Adak, T. 2007. Decreased glutathione-S-transferase activity: Diagnostic and protective role in vivax malaria. Clin. Biochem.,40, 377-382.

[43] Sweatman, G. K. and Williams, R. J. 1963. Comparative studies on the biology and morphology of Echinococcus granulosus from domestic livestock, moose and reindeer. Parasitol., 53:339-90.

[44] Symonds, D.A.; Merchenthaler, I. and Flaws, JA. 2008. Methoxychlor and estradiol induce oxidative stress DNA damage in the mouse ovarian surface epithelium. Toxicol Sci., 105(1): 182-7.

[45] Thompson, R.C.A. 1995. Biology and ystematic of Echinococcus. In Echinococcus and hydatid disease., Thompson, RCA.; Limbery, AJ. (eds), Wallingford UK: CAB Int., pp: 1-50.

[46] Yap, K. W. and Thompson, R. C. A. 1987. CTAB precipitation of cestode DNA. Parasitol, 7:220-222.

[47] Zepeda N1, Tirado R2, Copitin N1, Solano S2, Fernández AM2, Tato P2, Molinari JL. 2016. A Taenia crassiceps factor induces apoptosis of spleen CD4+T cells and TFG- $\beta$ and Foxp3 gene expression in mice. J Helminthol. 90(2):223-31.

[48] Zhang, W., Li, J., McManus, D.P., 2003. Concepts in immunology and diagnosis of hydatid disease. Clin. Microbiol.,Rev. 16, 1836. 
Table 1: Rostellar hooks and hook parts measurements of T. hydatigenacysticercus of imported (I) and local (L)

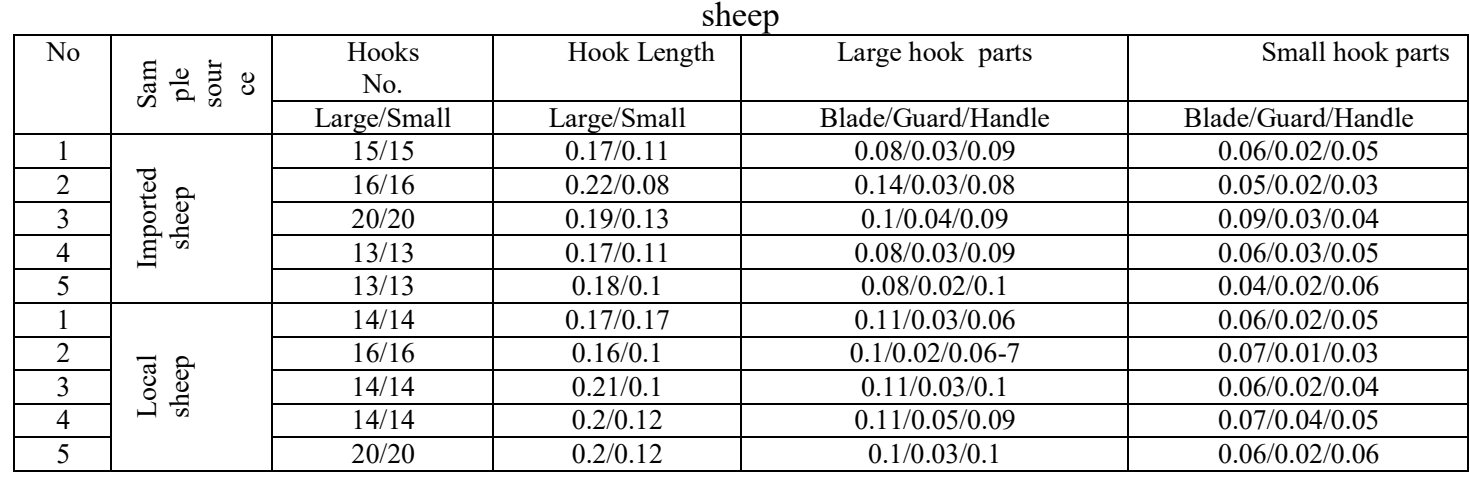

Table 2: oxidative stress markers levels in hepatic tissues Healty and infected sheep (mmoles/mg protein)

\begin{tabular}{|c|c|c|c|c|}
\hline Group & $\begin{array}{c}\text { (GSH) } \\
\text { Average } \pm \text { SD }\end{array}$ & $\begin{array}{c}\text { (MDA) } \\
\text { Average } \pm \text { SD }\end{array}$ & $\begin{array}{c}\text { (CAT) } \\
\text { Average } \pm \text { SD }\end{array}$ & $\begin{array}{c}\text { (GST) } \\
\text { Average } \pm \text { SD }\end{array}$ \\
\hline CI & $0.79 \pm 0.17^{\mathrm{a}, \mathrm{d}}$ & $0.028 \pm 0.0096^{\mathrm{a}, \mathrm{d}}$ & $0.423 \pm 0.050^{\mathrm{a}, \mathrm{c}}$ & $0.011 \pm 0.0014^{\mathrm{a}, \mathrm{c}}$ \\
\hline CL & $1.52 \pm 0.38^{\mathrm{b}, \mathrm{d}}$ & $0.027 \pm 0.002^{\mathrm{b}, \mathrm{d}}$ & $0.488 \pm 0.050^{\mathrm{b}, \mathrm{c}}$ & $0.0060 \pm 0.0024^{\mathrm{b}, \mathrm{c}}$ \\
\hline II & $1.45 \pm 0.27^{\mathrm{a}, \mathrm{c}}$ & $0.095 \pm 0.003^{\mathrm{a}, \mathrm{c}}$ & $0.66 \pm 0.0053^{\mathrm{a}, \mathrm{d}}$ & $0.022 \pm 0.0024^{\mathrm{a}, \mathrm{d}}$ \\
\hline IL & $2.96 \pm 0.18^{\mathrm{b}, \mathrm{c}}$ & $0.043 \pm 0.009^{\mathrm{b}, \mathrm{c}}$ & $0.66 \pm 0.0048^{\mathrm{b}, \mathrm{d}}$ & $0.0083 \pm 0.0018^{\mathrm{b}, \mathrm{d}}$ \\
\hline
\end{tabular}

CI: control healthy group of imported sheep; CL: control healthy group of local sheep; II: infected group of imported sheep; IL: infected group of local sheep

Table (3): Number of monomorphic (mono)and polymorphic (Poly)bands among 5 isolates in three primers:

\begin{tabular}{|c|c|c|c|c|c|c|}
\hline \multirow{2}{*}{ Primer } & \multicolumn{2}{|c|}{ Imported sheep } & \multicolumn{2}{c|}{ Local sheep } & \multicolumn{2}{c|}{ Imported and local sheep } \\
\cline { 2 - 7 } & Mono- & Polym- & Mono- & Poly- & Mono- & Polym- \\
\hline AP1 & 4 & 0 & 2 & 3 & 2 & 0 \\
\hline AP $_{2}$ & 6 & 2 & 1 & 5 & 1 & 0 \\
\hline AP $_{3}$ & 1 & 2 & 1 & 4 & 0 & 1 \\
\hline
\end{tabular}

Table (4): Average number of shared bands (SB) among individuals from the same and different isolates, including similarity coefficient (SC) and genetic differences (GD) of imported sheep and local sheep:

\begin{tabular}{|c|c|c|c|}
\hline Isolates & SB & SC\% & GD\% \\
\hline CI\&II & $\mathbf{1 8 3}$ & $\mathbf{4 9 \%}$ & $\mathbf{5 1 \%}$ \\
\hline CL\&IL & 107 & $\mathbf{3 8 \%}$ & $\mathbf{6 2 \%}$ \\
\hline
\end{tabular}
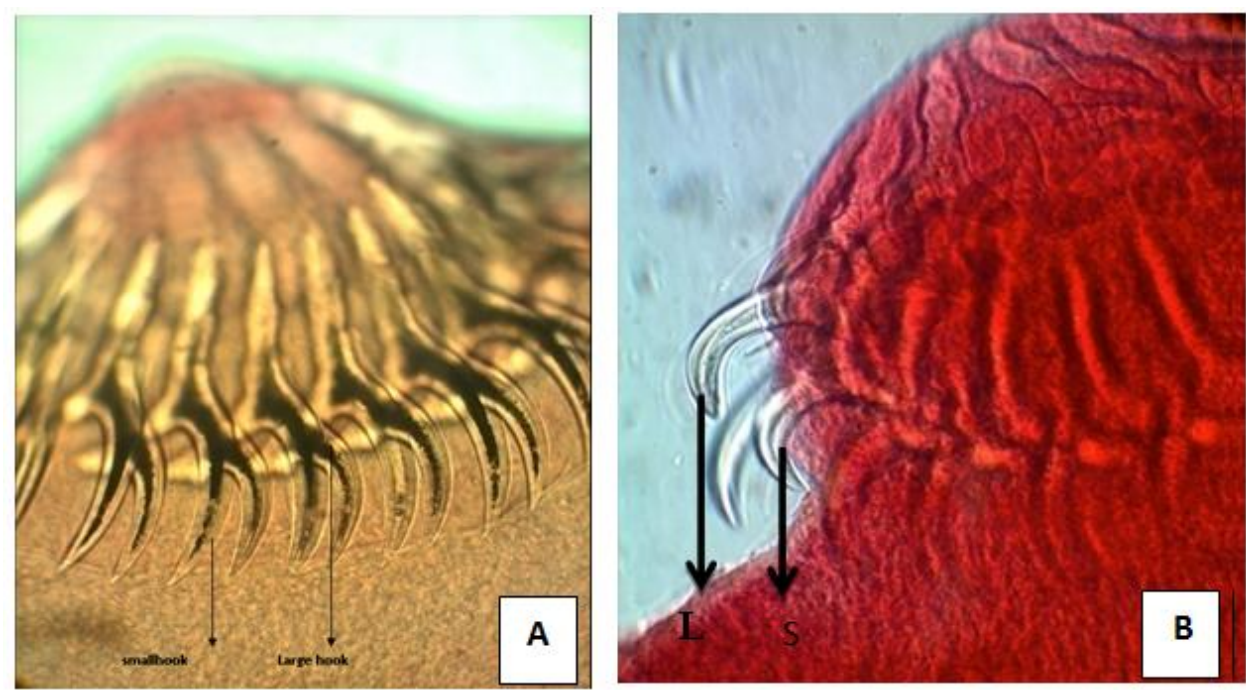

Fig. 1: Photomicrographs of the protoscolex of Taeniahydatigena recovered from local (A) and imported (B) sheep showing the rostellum carrying regular, alternate hammer shaped large (L) and small (S) hooks. 


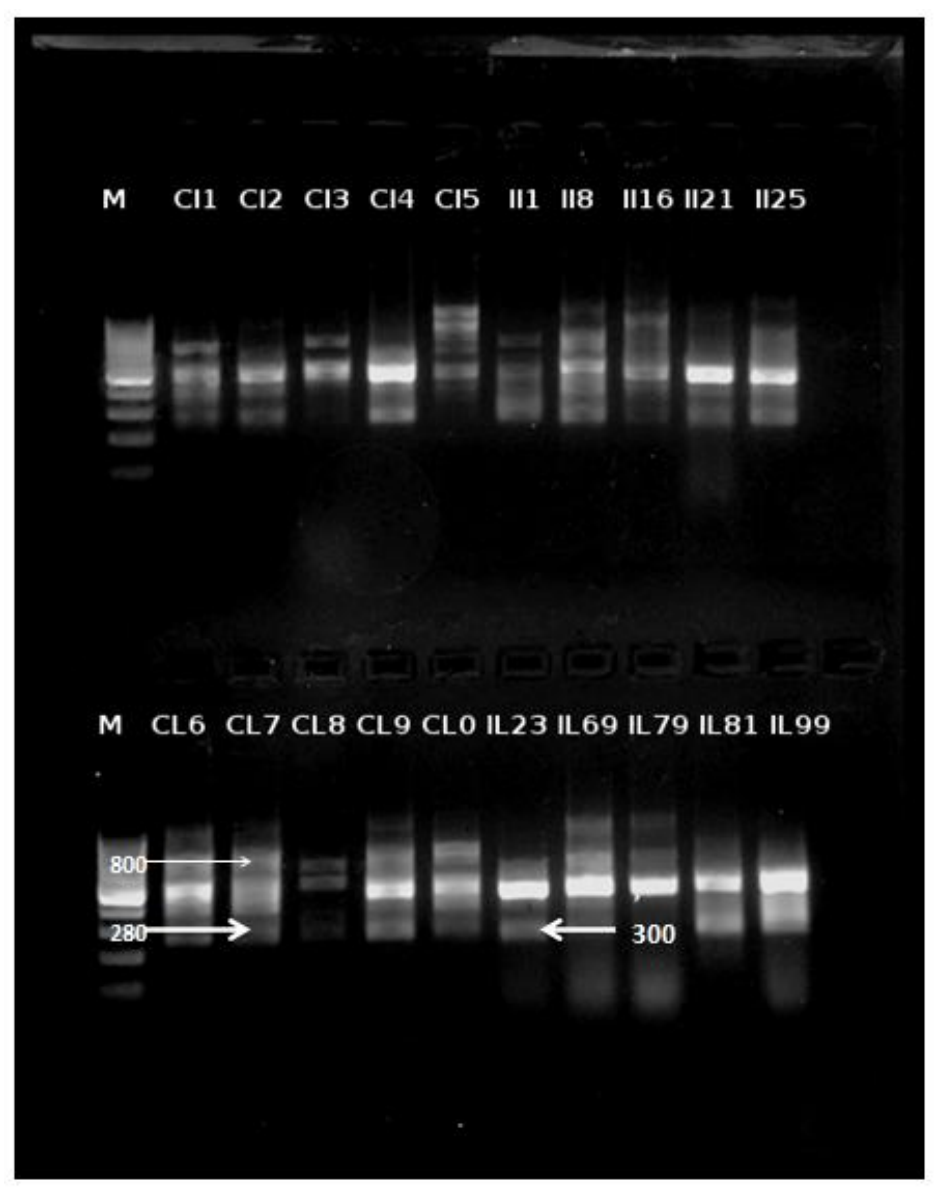

Fig. 2: 2\% agarose gel electrophoresis of RAPD-PCR using primer AP1. M: 1500 75 bp DNA ladder. CI/II:Control/infected-imported sheep. CL/IL: control/infected local sheep.

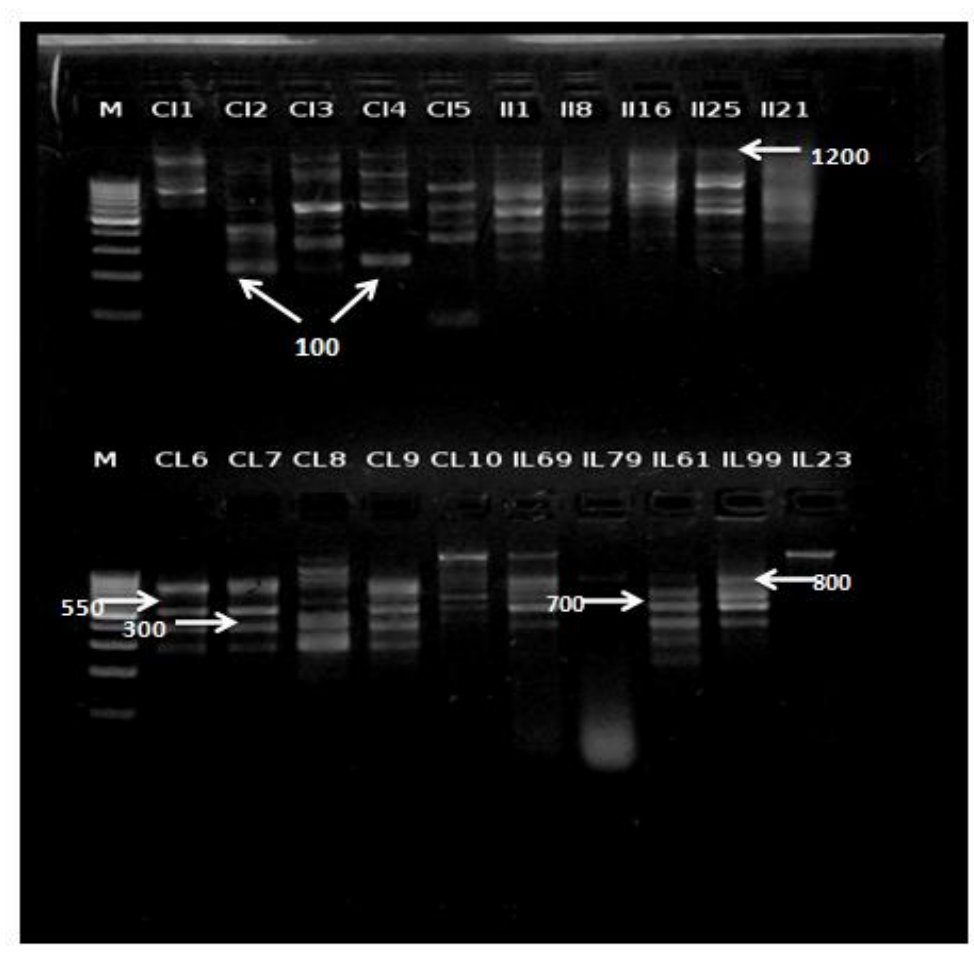

Fig.3: 2\% agarose gel electrophoresis of RAPD-PCR using primerAP2 M: 1500 75 bp DNA ladder. CI/II:control /infected imported sheep. CL/IL: control /infected local sheep. 


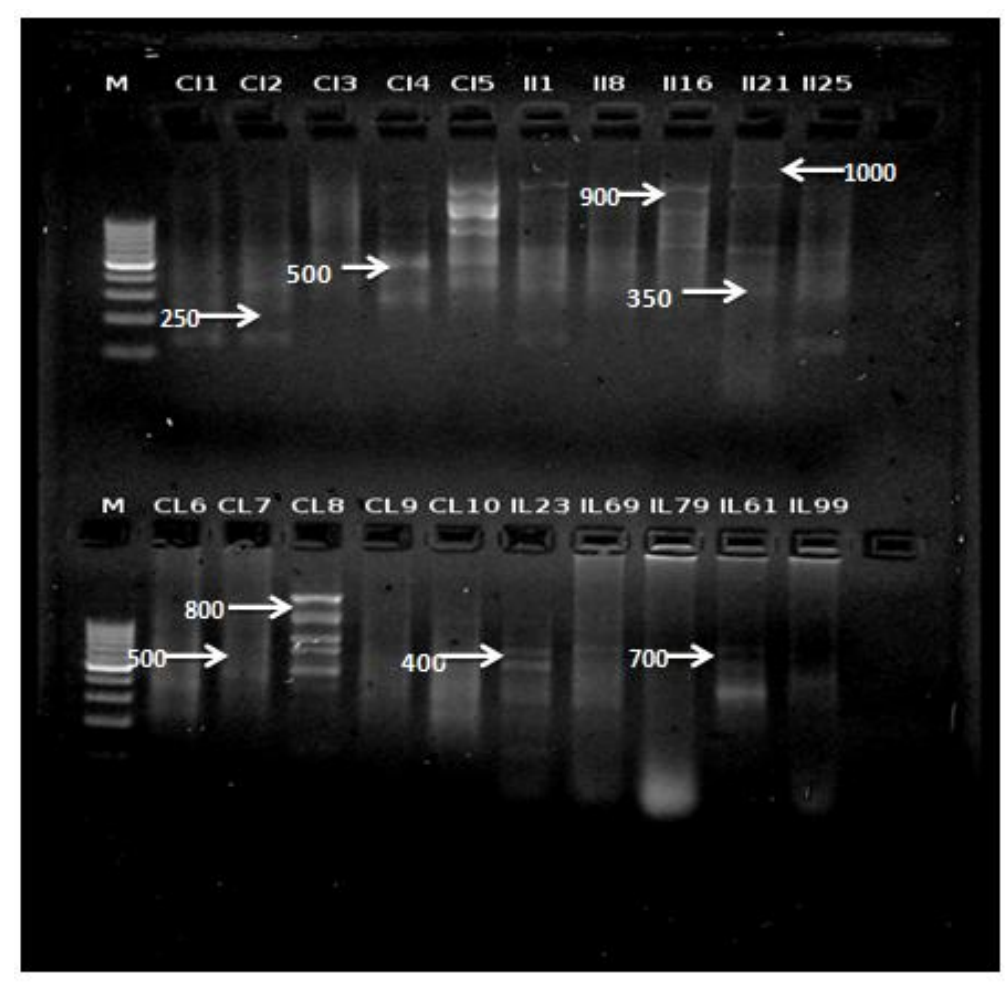

Figure 4:-2 \% agarose gel electrophoresis of RAPD-PCR using primer AP3. M: 1500 75 bp DNA ladder. CI/II: control /infected imported sheep, CL/IL: control/infected local sheep. 